\title{
Erythropoietin combined with granulocyte colony-stimulating factor enhances MMP-2 expression in mesenchymal stem cells and promotes cell migration
}

\author{
QIANG YU ${ }^{1,3}$, LONG CHEN $^{1,2}$, YONG YOU $^{3}$, CAN ZOU $^{2,3}$, \\ YOUSHUN ZHANG ${ }^{2}$, QIHUAN LIU ${ }^{1}$ and FANJUN CHENG ${ }^{1,3}$ \\ ${ }^{1}$ Department of Hematology; ${ }^{2}$ Experimental Medical Center, Dongfeng Hospital, \\ Yunyang Medical College, Shiyan 442008; ${ }^{3}$ Institute of Hematology, Union Hospital Tongji Medical College, \\ Huazhong University of Science and Technology, Wuhan 430022, P.R. China
}

Received July 12, 2010; Accepted October 13, 2010

DOI: $10.3892 / \mathrm{mmr} .2010 .387$

\begin{abstract}
Mesenchymal stem cells (MSCs) are promising clinical tools, but the molecular mechanisms that regulate the mobilization and homing of MSCs and cause invasion through extracellular matrix (ECM) barriers are unknown. Matrix metalloproteinase (MMP) degrades the ECM and promotes cell migration. In this study, we investigated MMP expression and cell migration after treatment with erythropoietin (EPO) and granulocyte colony-stimulating factor (G-CSF). Specifically, we studied whether EPO combined with G-CSF enhanced MMP expression and increased the in vitro motility of MSCs. Real-time PCR was used to detect the mRNA of MMPs and tissue inhibitors of metalloproteinase. Cell migration was evaluated by transwell and wound healing assays. Western blotting was used to detect changes in ERK1/2 protein levels. The results showed that EPO combined with G-CSF enhanced MMP-2 expression in MSCs, promoted MSC motility and activated the ERK1/2 signaling pathway. Thus, a combination treatment of EPO with G-CSF promoted cell migration by stimulating MMP-2 expression in MSCs and this appeared to be related to the ERK1/2 signaling pathway.
\end{abstract}

\section{Introduction}

Mesenchymal stem cells (MSCs), also known as marrow stromal cells, are a self-renewing population of multipotent cells present in bone marrow and many other adult tissues. They have the ability to differentiate into diverse mesodermal cell types, including osteoblasts, chondrocytes and adipocytes $(1,2)$. MSCs migrate from the bone marrow or peripheral blood

Correspondence to: Dr Fanjun Cheng, Department of Hematology, Dongfeng Hospital, Yunyang Medical College, Shiyan 442008, P.R. China

E-mail: chengfanjun001@sina.com.cn

Key words: matrix metalloproteinase, migration, ERK1/2 into damaged tissue. Transplantation experiments in animal models and humans have demonstrated that MSCs migrate to sites of injury, enhance wound healing (3) and promote tissue regeneration (4) and restoration of the bone marrow microenvironment after damage from myeloablative chemotherapy (5). However, the molecular mechanisms that regulate the mobilization and homing of MSCs are almost completely unknown.

The extracellular matrix (ECM) is present between the cells of all tissue types and acts as a barrier that prevents cells from migrating to distant target sites (6). Degradation of the basement membrane and the stromal ECM is crucial for cellular invasion and metastasis. Migrating cells use specific proteolytic enzymes to overcome matrix barriers, and matrix metalloproteinases (MMPs) play a crucial role in this process. The MMPs are a family of more than 24 zinc-dependent endopeptidase enzymes responsible for the proteolytic processing of ECM structural proteins in various physiological and pathological processes (7). The gelatinases MMP-2 and MMP-9 preferentially cleave denatured collagens (gelatin), laminin and collagen type IV, which are major constituents of basement membranes $(6,7)$. The activity of MMP-2 is inhibited by the tissue inhibitor of metalloproteinase (TIMP)-2, while MMP-9 is inhibited by TIMP-1, which binds to the highly conserved zinc-binding site of active MMPs at molar equivalence. The expression of MMPs is regulated by multiple cytokines and growth factors, which exert their effect by activating the mitogen-activated protein kinase (MAPK) signaling pathway inside the cell (8). ERK, one of the kinases in this pathway, regulates the expression of MMP-2 by stimulating the nuclear transcription factor AP-2 or activating the nuclear transcription factor Sp1 $(9,10)$.

Erythropoietin (EPO), a hematopoietic factor that stimulates the differentiation and proliferation of erythroid progenitor cells, alters the bone marrow micro-environment and stimulates bone marrow-derived endothelial progenitor cells to migrate from bone marrow into the blood by activating MMPs during endothelial progenitor cell (EPC) mobilization (11). Granulocyte colony-stimulating factor (G-CSF) also stimulates the expression of MMPs during the peripheral blood stem cell mobilization $(12,13)$, and is reported to stimulate 
Table I. RT-PCR primers.

\begin{tabular}{|c|c|c|c|c|}
\hline Target gene & Primer sequence & PCR conditions & PCR product $(\mathrm{bp})$ & Access no. \\
\hline GAPDH & $\begin{array}{l}\text { 5'CCAAAAGGGTCATCATCTCC 3' } \\
\text { 5'GTAGGCCATGAGGTCCACCAC3' }\end{array}$ & 25 cycles, $58^{\circ} \mathrm{C}$ & 661 & XM_001056329.1 \\
\hline MMP-2 & $\begin{array}{l}\text { 5'GGCCATGCCATGGGGCTGGA3' } \\
\text { 5'CCAGTCTGATTTGATGCTTC3' }\end{array}$ & 28 cycles, $64^{\circ} \mathrm{C}$ & 761 & NM_031054.1 \\
\hline MMP-9 & $\begin{array}{l}\text { 5'AACCCTGGTCACCGGACTTC3' } \\
\text { 5'CACCCGGTTGTGGAAACTCAC3' }\end{array}$ & 30 cycles, $55^{\circ} \mathrm{C}$ & 234 & NM_031055.1 \\
\hline TIMP-1 & $\begin{array}{l}\text { 5'CATCGAGACCACCTTAT3' } \\
\text { 5'CACCCCACAGCCAGCACTATA3' }\end{array}$ & 25 cycles, $57^{\circ} \mathrm{C}$ & 191 & NM_053819.1 \\
\hline TIMP-2 & $\begin{array}{l}\text { 5'CAAAGCAGTGAGCGAGAAGG3' } \\
\text { 5'ACCCAGTCCATCCAGAGGGA3' }\end{array}$ & 25 cycles, $57^{\circ} \mathrm{C}$ & 392 & NM_021989.2 \\
\hline
\end{tabular}

MSC migration by inducing MMP expression (14). However, the levels of MMP expression and the effect on MSCs of EPO combined with G-CSF are unknown. In this study, we investigated whether EPO combined with G-CSF enhances MMP expression and increases the motility of MSCs.

\section{Materials and methods}

Cell culture. MSC cultures used the classical adhering method (15). Briefly, male Sprague-Dawley rats, 6-12 weeks of age, were sacrificed by cervical dislocation. The tibiae and femora were aseptically removed, adherent soft tissue was thoroughly debrided and bone marrow was collected. Bone marrow samples were initially plated in $15 \mathrm{ml}$ DMEM (Gibco) supplemented with 10\% fetal bovine serum (FBS) (Hyclone) at $1 \times 10^{7}$ cells $/ \mathrm{ml}$ in culture flasks, and incubated at $37^{\circ} \mathrm{C}$ with $5 \%$ humidified $\mathrm{CO}_{2}$. After $24 \mathrm{~h}$, half the medium was removed and non-adherent cells were discarded. The culture medium was replaced with fresh serum-supplemented medium every 2-3 days thereafter, until $80-90 \%$ confluence was reached. Cells were trypsinized ( $0.25 \%$ trypsin; Sigma, USA), washed and resuspended in culture medium (DMEM with 10\% FBS) at a ratio of 1:3. The same method was used for subculturing.

Adipogenic differentiation. To induce adipogenic differentiation in vitro, MSCs were seeded into a 12 -well plate and treated with adipogenic medium (DMEM supplemented with 10\% FBS, $0.5 \mathrm{mM}$ 3-isobutyl-1-methylxanthine, $1 \mu \mathrm{M}$ dexamethasone, $0.2 \mathrm{mM}$ indomethacin and $10 \mu \mathrm{M}$ insulin) (Sigma) (16), which was changed every 2-3 days until confluence was reached. Adipocytes were identified with Sudan III (Sigma) staining.

Osteogenic differentiation. To induce osteogenic differentiation, MSCs were cultured in osteogenic medium (DMEM supplemented with $10 \% \mathrm{FBS}, 0.1 \mu \mathrm{M}$ dexamethasone, $10 \mathrm{mM}$ $\beta$-glycerolphosphate and $50 \mu \mathrm{M}$ vitamin C) (Sigma) (17) for 2 weeks, with medium changes every 2-3 days. To verify osteogenic differentiation, Von Kossa's method was used to stain calcium deposits.

Flow cytometric analysis. For flow cytometric analysis, cultured MSCs were harvested by trypsinization. Cell aliquots were incubated with purified monoclonal antibody against CD90, CD45 (eBioscience), CD29 (Biolegend), CD34 or CD44 (Santa Cruz) for $30 \mathrm{~min}$. Cells were washed with PBS and centrifuged at $10,000 \mathrm{~g}$ for $5 \mathrm{~min}$. The supernatant was removed and cells were incubated with fluorescein isothiocyanate (FITC)- $\operatorname{IgG}$ (Biolegend). After $30 \mathrm{~min}$, cells were washed with PBS and analyzed by a FACSCalibur flow cytometer (BD Biosciences). Data were analyzed using CellQuest software (BD).

$R T$-PCR. $\mathrm{P}_{3}$ MSCs were plated in $2 \mathrm{ml}$ DMEM with $10 \% \mathrm{FBS}$ at $5 \times 10^{5}$ cells $/ \mathrm{ml}$ in 6 -well plates and incubated at $37^{\circ} \mathrm{C}$ in a humidified $5 \% \mathrm{CO}_{2}$ incubator. MSCs were synchronized with DMEM with $2 \%$ FBS at $80 \%$ confluence. After treatment with EPO (1 IU/ml), G-CSF $(0.1 \mathrm{ng} / \mathrm{ml}, 1 \mathrm{ng} / \mathrm{ml})$ and EPO $(1 \mathrm{IU} / \mathrm{ml})+\mathrm{G}-\mathrm{CSF}(0.1 \mathrm{ng} / \mathrm{ml}, 1 \mathrm{ng} / \mathrm{ml})$ for $12 \mathrm{~h}$, MSCs were harvested. Total RNA was extracted with TRIzol reagent (Invitrogen) and cDNA synthesized with a Fermentas kit. PCR reactions were performed in $20 \mu l$ reaction volumes with the primers listed in Table I. cDNA was amplified using a Veriti 96-Well Thermal Cycler (Applied Biosystems, Boston, MA, USA) at $94^{\circ} \mathrm{C}$ for $40 \mathrm{sec}$, at the annealing temperatures indicated in Table I for $30 \mathrm{sec}$, and at $72^{\circ} \mathrm{C}$ for $45 \mathrm{sec}$, with a final extension at $72^{\circ} \mathrm{C}$ for $10 \mathrm{~min}$. After amplification, PCR products were resolved on $1.5 \%$ agarose gels and visualized by ethidium bromide staining.

Transwell assays. MSC migration was analyzed using the Costar transwell chamber system with membrane filters with a pore size of $8 \mu \mathrm{m}$ and a diameter of $6.5 \mathrm{~mm}$ (Costar). The upper compartment was filled with $200 \mu \mathrm{l}$ DMEM with $2 \%$ FBS containing $5 \times 10^{4}$ cells $/ \mathrm{ml}$ MSCs. The lower compartment was filled with $400 \mu \mathrm{l}$ DMEM with $2 \%$ FBS and EPO, G-CSF, or EPO combined with G-CSF at the indicated concentrations as chemoattractants. The invasion chambers were incubated at $37^{\circ} \mathrm{C}$ in a humidified air atmosphere with $5 \% \mathrm{CO}_{2}$. After $12 \mathrm{~h}$, the invasion chambers were removed, washed with PBS three times and fixed with $4 \%$ paraformaldehyde for $15 \mathrm{~min}$. Adherent cells attached to the upper surface of the filter were wiped and washed with PBS three times. Invasion chambers were incubated for $10 \mathrm{~min}$ after staining with $0.5 \%$ propidium iodide. Cells were counted under a fluorescence microscope (Olympus, Japan). 
A

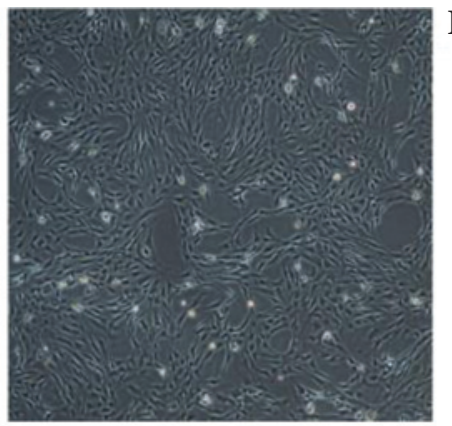

D
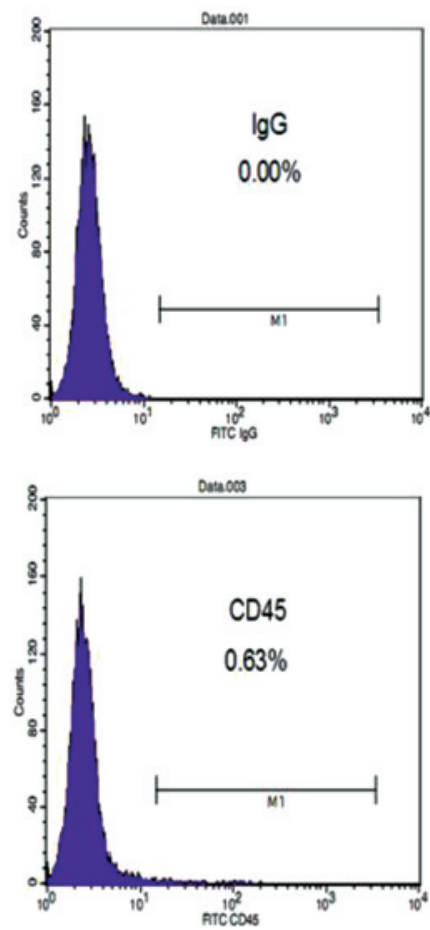

B
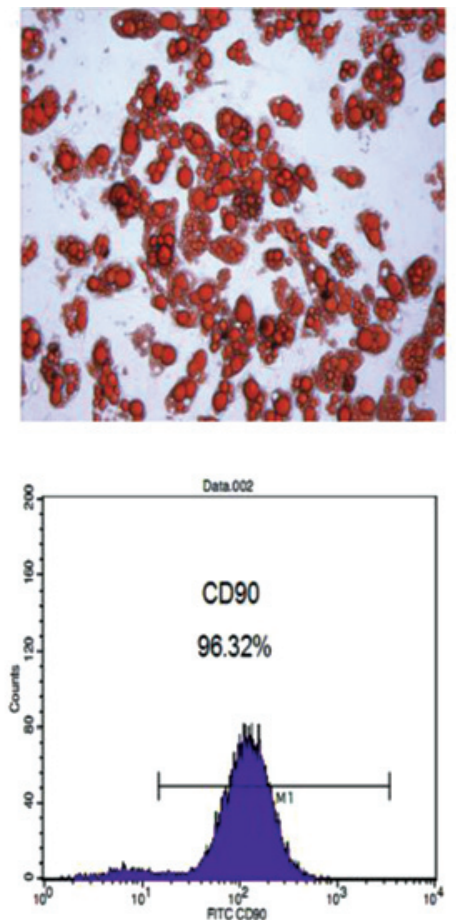

Datacos

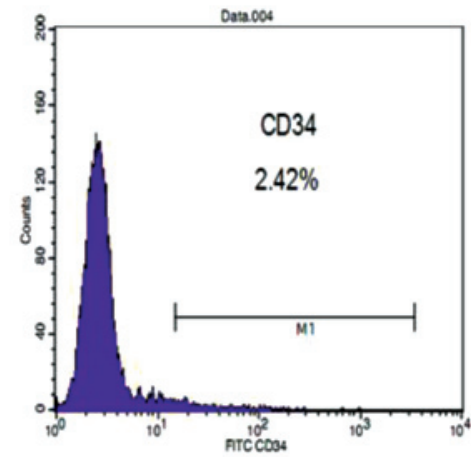

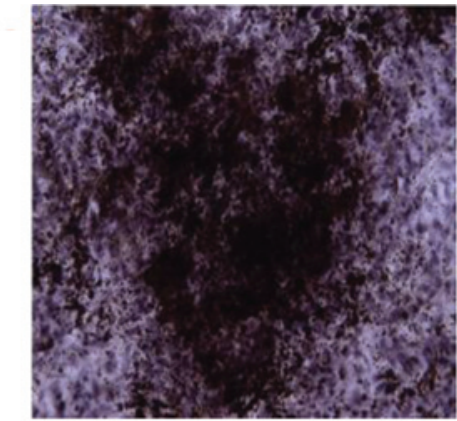
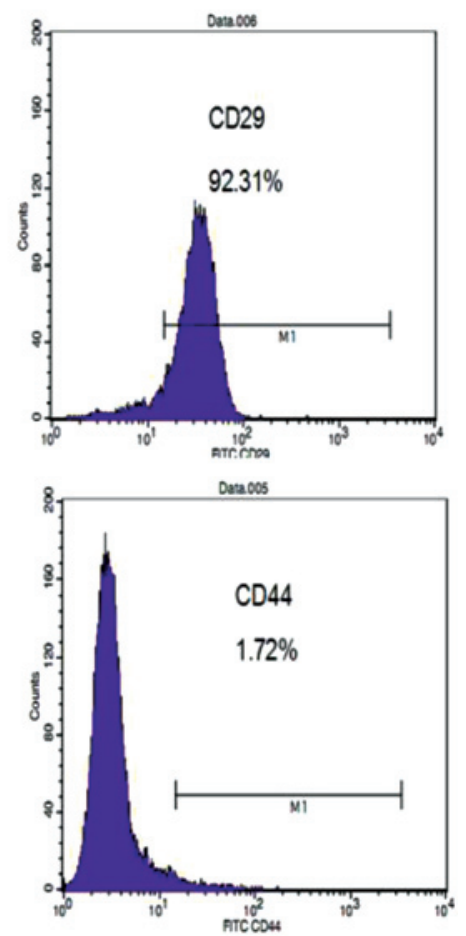

Figure 1. Characterization of expanded MSCs. (A) $\mathrm{P}_{3}$ MSCs grown as fibroblast-like cells. Magnification, x40. (B) Adipogenic differentiation potential of $\mathrm{P}_{3}$ MSCs by Sudan III staining, observed by phase contrast microscopy. Magnification, x10. (C) Osteogenic differentiation potential of $\mathrm{P}_{3} \mathrm{MSCs}$. Von Kossa's staining by phase contrast microscopy. Magnification, x10. (D) Immunophenotypic characterization of MSCs. Cells positively expressed the antigens CD90 and CD29, but were negative for antigens CD34, CD44 and CD45.

Wound healing assay. For wound healing assays, MSCs were plated in 24-well plates (CytoSelect 24-Well Wound Healing Assay; Cell Biolabs) and incubated in DMEM with 10\% FBS. At confluence, the inserts were removed and the MSCs were washed two times with PBS and incubated in medium with $10 \%$ FBS and EPO, G-CSF or EPO in combination with G-CSF. After $18 \mathrm{~h}$, the medium was discarded and the cells were washed with PBS three times, before fixing with $4 \%$ paraformaldehyde for $15 \mathrm{~min}$ and staining with $0.1 \%$ crystal violet. Invasion or growth into the scored area was observed and documented with a phase contrast microscope (Olympus).

Western blotting. After treatment with EPO (1 IU/ml), G-CSF $(0.1 \mathrm{ng} / \mathrm{ml}, 1 \mathrm{ng} / \mathrm{ml})$ or EPO $(1 \mathrm{IU} / \mathrm{ml})+\mathrm{G}-\mathrm{CSF}(0.1 \mathrm{ng} /$ $\mathrm{ml}, 1 \mathrm{ng} / \mathrm{ml}$ ) for $3 \mathrm{~h}$, the MSCs were harvested and lysed in $150 \mu \mathrm{l}$ of RIPA lysis buffer by incubation on ice for $1 \mathrm{~h}$. Extracts were centrifuged at $10,000 \mathrm{~g}$ for $5 \mathrm{~min}$ to remove cell debris. Protein concentrations were determined by the Bradford method. After the addition of 5X loading buffer, equal amounts of protein (15 $\mu \mathrm{g} /$ lane) were analyzed by
SDS-polyacrylamide gel electrophoresis (12\% separating gel and 5\% stacking gel). Proteins were transferred to nitrocellulose membranes (Millipore), which were blocked with Tris Buffered Saline with Tween-20 (TBST) containing 5\% skim milk. After washing with TBST, membranes were incubated overnight at $4^{\circ} \mathrm{C}$ with 1:1,000 diluted primary antibody against ERK1/2 (Santa Cruz Biotechnology Inc., CA, USA), washed with TBST three times and incubated in horseradish peroxidase (HRP)-labeled secondary antibody (1:10,000; Sigma) for $1 \mathrm{~h}$. Blots were visualized by enhanced chemiluminescence. Protein expression levels were analyzed using Image Quant TL software. $\beta$-actin immunoblots was performed on corresponding cells using polyclonal antibody against $\beta$-actin (Sigma).

Statistical analysis. Data were statistically analysed using SPSS 10.0 software. Comparisons between experimental and control groups were made by the t-test. All values were expressed as the mean \pm standard error. $\mathrm{P}<0.05$ was considered statistically significant. 

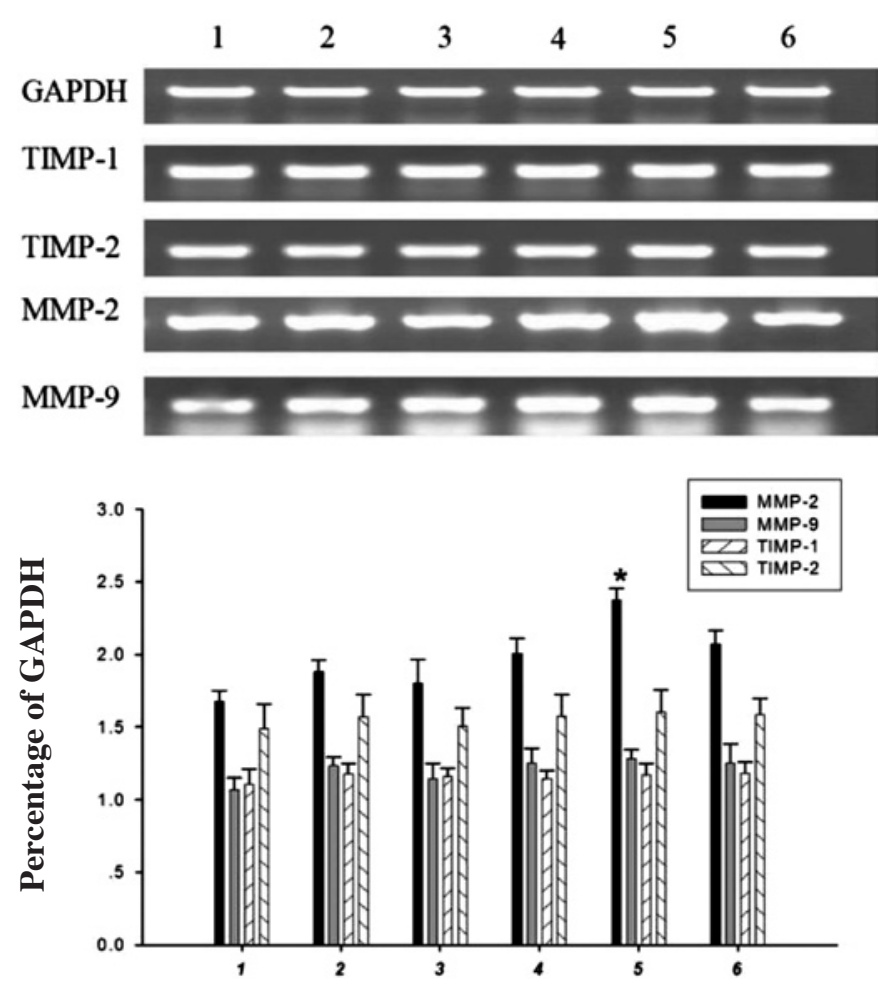

Figure 2. Regulation of MSC MMP and TIMP expression by EPO with G-CSF. RT-PCR was performed with GAPDH as a reference. Results are represented as the mean \pm standard error for the ratio of MMP or TIMP mRNA to GAPDH mRNA in MSCs incubated with the indicated concentrations of EPO and G-CSF. 1, control; 2, EPO (1 IU/ml); 3, G-CSF (0.1 ng/ml); 4, G-CSF ( $1 \mathrm{ng} / \mathrm{ml}) ; 5$, EPO (1 IU/ml) combined with G-CSF $(0.1 \mathrm{ng} / \mathrm{ml})$; 6, EPO (1 IU/ml) combined with G-CSF $(1 \mathrm{ng} / \mathrm{ml})$. *P<0.05 vs. control and single-factor groups.

\section{Results}

Identification and expansion of MSCs. MSCs were cultured from the mononuclear cell fraction of bone marrow samples. After several changes of medium, hematopoietic stem cells were removed gradually based on non-adherence. Adherent cells were passaged three times, yielding $\mathrm{P}_{3} \mathrm{MSCs}$ grown uniformly to fibroblast-like cells (Fig. 1A).

The potential of the expanded cells to differentiate in vitro into adipogenic and osteogenic lineages was next tested. $\mathrm{P}_{3}$ MSCs were cultured in induction medium for 2 weeks and adipogenesis was demonstrated by staining for lipid droplets with Sudan III (Fig. 1B). Calcium deposits in differentiated osteogenic cells were stained black using Von Kossa's method (Fig. 1C). The results showed that MSCs were capable of differentiation into two mesenchymal cell types.

FACS analysis was used to examine the expression of the MSC markers CD90 and CD29, and the hematopoietic membrane antigens CD34, CD45 and CD44. The results showed that MSCs were positive for CD90 and CD29, and negative for CD34, CD45 and CD44. This was consistent with generally accepted MSC immunophenotypes (Fig. 1D).

Regulation of MMP and TIMP expression in MSCs by EPO with G-CSF. Quantitative determination of MMP-2, MMP-9, TIMP-1 and TIMP-2 mRNA compared to GAPDH expression was achieved by RT-PCR. EPO and G-CSF increased
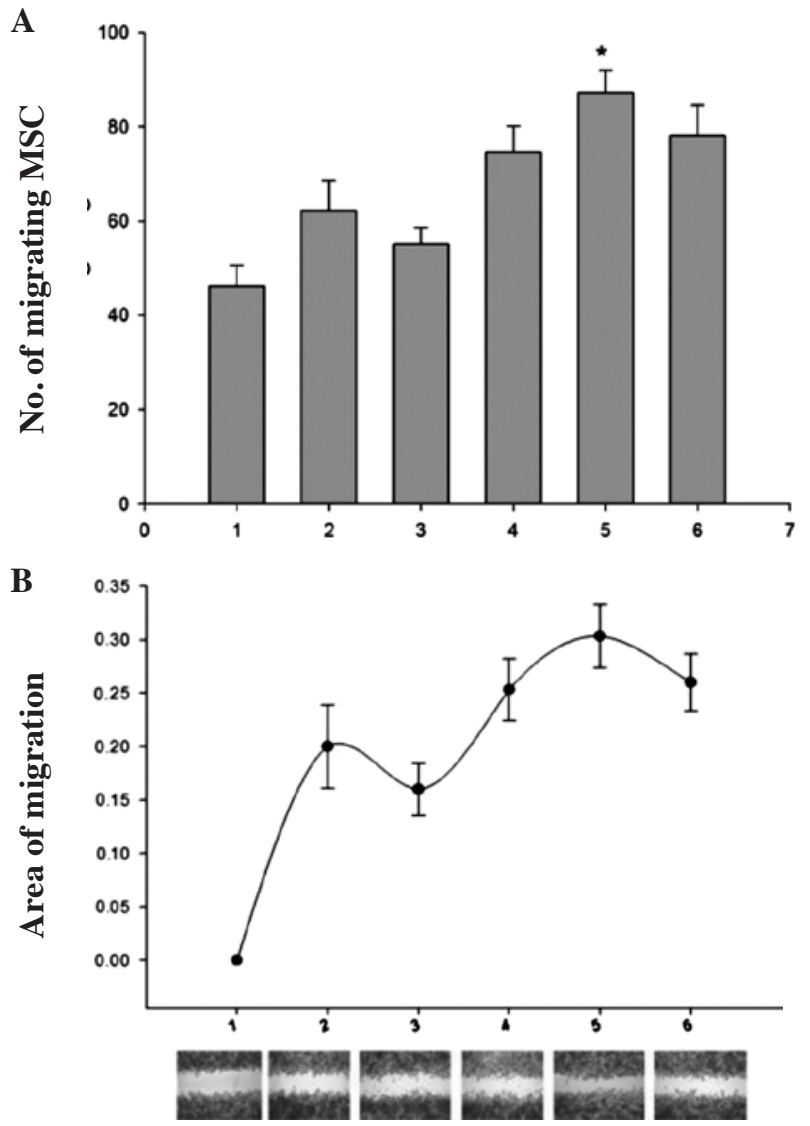

Figure 3. In vitro migration capacity of MSCs. (A) Transwell assay. (B) Wound healing assay analyzing the migration capacity of MSCs incubated with the indicated concentrations of EPO and G-CSF. 1, control; 2, EPO (1 IU/ml); 3, G-CSF (0.1 ng/ml); 4, G-CSF (1 ng/ml); 5, EPO (1 IU/ml) combined with G-CSF $(0.1 \mathrm{ng} / \mathrm{ml}) ; 6$, EPO $(1 \mathrm{IU} / \mathrm{ml})$ combined with G-CSF $(1 \mathrm{ng} / \mathrm{ml}) .{ }^{*} \mathrm{P}<0.05$ vs. control and single-factor groups.

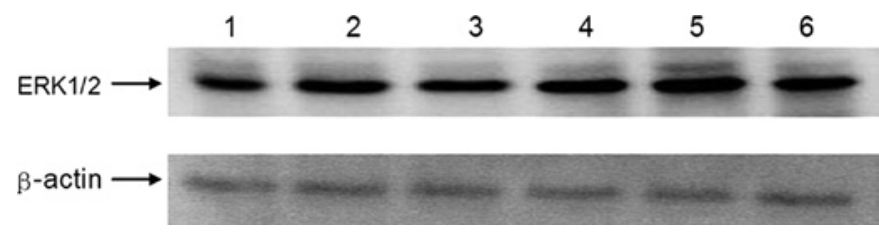

Figure 4. Effect of EPO combined with G-CSF on the ERK1/2 signal pathway. Immunoblot analysis detected ERK1/2 and $\beta$-actin in MSCs incubated with the indicated concentrations of EPO and G-CSF. ERK1/2 relative expression was standardized to $\beta$-actin levels. 1, control; 2 , EPO $(1 \mathrm{IU} / \mathrm{ml})$; 3, G-CSF $(0.1 \mathrm{ng} / \mathrm{ml}) ; 4$, G-CSF $(1 \mathrm{ng} / \mathrm{ml}) ; 5$, EPO (1 IU/ml) combined with G-CSF $(0.1 \mathrm{ng} / \mathrm{ml}) ; 6$, EPO $(1 \mathrm{IU} / \mathrm{ml})$ combined with G-CSF $(1 \mathrm{ng} / \mathrm{ml})$. ${ }^{*} \mathrm{P}<0.05$ vs. control or single-factor groups.

the expression of MMPs. To investigate whether a combination of EPO and G-CSF influenced the secretion of MMP and TIMP from MSCs, MSCs were incubated with different concentrations of EPO or G-CSF, or with EPO in combination with G-CSF, for $12 \mathrm{~h}$. As shown in Fig. 2, the level of MMP-2 mRNA was clearly increased in the group of cells treated with a combination of EPO $(1 \mathrm{IU} / \mathrm{ml})$ and G-CSF $(0.1 \mathrm{ng} / \mathrm{ml})$, compared to the control group, either of the single factor groups, or EPO $(1 \mathrm{IU} / \mathrm{ml})$ in combination with G-CSF $(1 \mathrm{ng} / \mathrm{ml})$. MMP-9, TIMP-1 and TIMP-2 mRNA showed no significant differences between treatment groups. These 
results indicate that EPO combined with G-CSF up-regulated MMP-2 mRNA.

$M S C$ in vitro migration capacity. To investigate whether EPO combined with G-CSF promoted MSC migration, two different methods were used. First, MSCs were incubated with several concentrations of EPO, G-CSF or EPO combined with G-CSF, in transwell chambers. After $12 \mathrm{~h}$, the number of invading cells was determined. It was found that EPO (1 IU/ml) combined with G-CSF $(0.1 \mathrm{ng} / \mathrm{ml})$ clearly increased the invasion of MSCs through reconstituted basement membranes, compared to the control or single factor groups (Fig. 3A). Second, wound healing assays were used to evaluate the MSC migration capability. MSCs were incubated with several concentrations of EPO, G-CSF or EPO in combination with G-CSF for $18 \mathrm{~h}$, and analyzed for migratory potential. The results showed that EPO $(1 \mathrm{IU} / \mathrm{ml})$ with G-CSF $(0.1 \mathrm{ng} / \mathrm{ml})$ significantly increased the distance of MSC migration as compared to the control or single factor groups (Fig. 3B). These results indicate that EPO in combination with G-CSF promoted MSC migration.

Effect of EPO with G-CSF on the ERK1/2 signal pathway. To determine whether EPO in combination with G-CSF influenced the ERK1/2 signaling pathway in relation to cell migration, MSCs were incubated with different concentrations of EPO, G-CSF or EPO in combination with G-CSF for $3 \mathrm{~h}$. ERK1/2 protein levels were significantly increased in the group treated with EPO $(1 \mathrm{IU} / \mathrm{ml})$ combined with G-CSF $(0.1 \mathrm{ng} / \mathrm{ml})$, compared to the control or single factor groups and to the group treated with EPO (1 IU/ml) combined with G-CSF (1 ng/ml) (Fig. 4).

\section{Discussion}

To play a decisive role in tissue repair and regeneration processes, MSCs must egress from the bone marrow into the blood circulation (18). Degradation of the basement membrane is an important part of MSC migration, and MMPs play an important role in this process. In this study, we analyzed the effects of EPO combined with G-CSF on MSC migration. The expression of MMP-2 after treatment with EPO in combination with G-CSF was enhanced, while the expression of MMP-9, TIMP-2 and TIMP-1 was unchanged. In addition, we demonstrated that the capability of MSC migration was increased when cells were treated with EPO combined with G-CSF, and that the effect was probably related to the ERK1/2 signal pathway.

MSC mobilization and homing is extremely complex, and its molecular mechanisms are almost unknown. However, invasive MSCs often secrete proteinases, which are essential to their migratory activity. These proteinases degrade the ECM and regulate the transmigration and invasion of the endothelium basement membrane during MSC migration. MMP plays an important role in this process. EPO enhances the activity of MMPs expressed from bone marrow-derived MSCs and enhances MSC motility $(11,14,19,20)$. In addition, MMP expression is increased during the induction of peripheral blood stem cell mobilization by G-CSF (12). Hence, we considered whether EPO combined with G-CSF was capable of enhancing the expression of MMPs and increasing MSC motility.
EPO with G-CSF enhanced MMP-2 secretion from MSCs, while the expression of MMP-9 did not differ compared to the control or single-factor treatment groups. TIMP-2, which is an MMP-2-specific inhibitor, is essential for MSC invasion, since MMP-2 proenzyme activation requires TIMP-2. However, TIMP-1 hinders MSC invasion, probably by inhibiting MMP activity. Therefore, we also detected the expression of TIMP-1 and TIMP-2 in cells treated with EPO, G-CSF or EPO combined with G-CSF, and found no difference between any of the treatment groups. On the basis of these results, we investigated the effect of the treatments on MSC migration using transwell and wound healing assays. The results indicated that EPO combined with G-CSF clearly enhanced the invasive capacity of MSCs and promoted their migration. De Becker et al found that the capacity for in vitro transendothelial migration was reduced by blocking antibodies against MMP-2 and by siRNA knockdown of MMP-2 in MSCs (21). Ries et al showed that chemotactic invasion of MSCs through human ECM-coated transwell chambers was hindered by inhibition of the proteases. Down-regulation of MMP-2 significantly impairs the migration of MSCs (22). Therefore, we hypothesize that MMP-2 plays a crucial role in MSC migration by degrading the ECM, and that EPO combined with G-CSF promotes MSC migration by inducing the expression of MMP-2. We also detected the expression of the ERK1/2 signal pathway after EPO and G-CSF treatment, and found that EPO with G-CSF increased the expression of ERK1/2 in MSCs. These results indicate that ERK1/2 is probably part of the signal pathway that stimulates cell migration.

In conclusion, this study provides evidence that EPO combined with G-CSF enhances the expression of MMP-2, increases MSC migration ability and may affect the ERK1/2 signaling pathway. Based on these findings, we hypothesize that MSCs treated with EPO combed with G-CSF may be more easily mobilized from bone marrow into the peripheral blood circulation, providing a potential program for stem cell mobilization.

\section{Acknowledgements}

This study was supported by grants from the Hubei Provincial Science and Technology Agency, the National Natural Foundation of China (No. 2008 ZRY1556) and the Hubei Provincial Yunyang Medical College Creative Team Foundation of China (No. 2008CXX02).

\section{References}

1. Pittenger MF, Mackay AM, Beck SC, et al: Multilineage potential of adult human mesenchymal stem cells. Science 284: 143-147, 1999.

2. Zipori D: The stem state: plasticity is essential, whereas self-renewal and hierarchy are optional. Stem Cells 23: 719-726, 2005.

3. Mackenzie TC and Flake AW: Human mesenchymal stem cells persist, demonstrate site-specific multipotential differentiation, and are present in sites of wound healing and tissue regeneration after transplantation into fetal sheep. Blood Cells Mol Dis 27: 601-604, 2001.

4. Kawada H, Fujita J, Kinjo K, et al: Nonhematopoietic mesenchymal stem cells can be mobilized and differentiate into cardiomyocytes after myocardial infarction. Blood 104: 3581-3587, 2004 
5. Koc ON, Gerson SL, Cooper BW, et al: Rapid hematopoietic recovery after coinfusion of autologous-blood stem cells and culture-expanded marrow mesenchymal stem cells in advanced breast cance $\mathrm{r}$ patients receiving high-dose chemotherapy. J Clin Oncol 18: 307-316, 2000.

6. Kalluri R: Basement membranes: structure, assembly and role in tumour angiogenesis. Nat Rev Cancer 3: 422-433, 2003.

7. Visse $\mathrm{R}$ and Nagase $\mathrm{H}$ : Matrix metalloproteinases and tissue inhibitors of metalloproteinases: structure, function, and biochemistry. Circ Res 92: 827-839, 2003.

8. Westermarck $\mathbf{J}$ and Kahari VM: Regulation of matrix metalloproteinase expression in tumor invasion. FASEB J 13: 781-792, 1999.

9. Guccione M, Silbiger S, Lei J, et al: Estradiol upregulates mesangial cell MMP-2 activity via the transcription factor AP-2 Am J Physiol Renal Physiol 282: F164-F169, 2002.

10. Kuo L, Chang HC, Leu TH, et al: Src oncogene activates MMP-2 expression via the ERK/Sp1 pathway. J Cell Physiol 207: 729-734, 2006.

11. Heeschen C, Aicher A, Lehmann R, et al: Erythropoietin is a potent physiologic stimulus for endothelial progenitor cell mobilization. Blood 102: 1340-1346, 2003.

12. Saito T, Usui N, Asai O, et al: Elevated serum levels of human matrix metalloproteinase-9 (MMP-9) during the induction of peripheral blood stem cell mobilization by granulocyte colonystimulating factor (G-CSF). J Infect Chemother 13: 426-428, 2007.

13. Carstanjen D, Ulbricht N, Iacone A, Regenfus M and Salama A: Matrix metalloproteinase-9 (gelatinase B) is elevated during mobilization of peripheral blood progenitor cells by G-CSF Transfusion 42: 588-596, 2002.

14. Koh SH, Noh MY, Cho GW, Kim KS and Kim SH: Erythropoietin increases the motility of human bone marrow multipotent stromal cells (hBM-MSCs) and enhances the production of neurotrophic factors from hBM-MSCs. Stem Cells and Development 18 : 411-421, 2009
15. Tang J, Xie Q, Pan G, et al: Mesenchymal stem cells participate in angiogenesis and improve heart function in rat model of myocardial ischemia with reperfusion. Eur J Cardiothoracic Surg 3: 353-361, 2006

16. Nakamura T, Shiojima S, Hirai Y, et al: Temporal gene expression changes during adipogenesis in human mesenchymal stem cells. Biochem Biophys Res Comm 303: 306-312, 2003.

17. Jaiswal N, Haynesworth SE, Caplan AI, et al: Osteogenic differentiation of purified, culture-expanded human mesenchymal stem cells in vitro. J Cell Biochem 64: 295-312, 1997.

18. Roufosse CA, Direkze NC, Otto WR and Wright NA: Circulating mesenchymal stem cells. Int J Biochem Cell Biol 36: 585-597, 2004.

19. Zwezdaryk KJ, Coffelt SB, Figueroa YG, et al: Erythropoietin, a hypoxia-regulated factor, elicits a pro-angiogenic program in human mesenchymal stem cells. Exp Hematol 35: 640-652, 2007.

20. Roufosse CA, Direkze NC, Otto WR and Wright NA: The effect of recombinant human erythropoietin on the migration of bone marrow derived mesenchymal stem cells in vitro. Chin J Hematol 29: 811-814, 2008.

21. De Becker A, van Hummelen P, Bakkus M, Vande Broek I, De Wever J, De Waele M and van Riet I: Migration of cultureexpanded humanmesenchymal stem cells through bone marrow endothelium is regulated by matrix metalloproteinase- 2 and tissue inhibitor of metalloproteinase-3. Haematologica 92: 440-449, 2007.

22. Ries C, Egea V, Karow M, Kolb H, Jochum $M$ and Neth $P$ : MMP-2, MT1-MMP and TIMP-2 are essential for the invasive capacity of human mesenchymal stem cells: differential regulation by inflammatory cytokines. Blood 109: 4055-4063, 2007. 